\title{
Biodiesel Production Based in Microalgae: A Biorefinery Approach
}

\author{
Lauren Espinosa González¹, Gisel Chenard Díaz², Donato Alexandre Gomes Aranda1, \\ Yordanka Reyes Cruz ${ }^{1}$, Mariana Monteiro Fortes ${ }^{1}$ \\ ${ }^{1}$ Greentec Laboratory, School of Chemistry, Federal University of Rio de Janeiro, Rio de Janeiro, Brazil \\ ${ }^{2}$ Grand Valle Bio Energy Ltd., Biodiesel Factory, Porto Real, Rio de Janeiro, Brazil \\ Email: laurenespinosagonzalez@yahoo.es
}

Received 1 June 2015; accepted 10 July 2015; published 13 July 2015

Copyright @ 2015 by authors and Scientific Research Publishing Inc.

This work is licensed under the Creative Commons Attribution International License (CC BY).

http://creativecommons.org/licenses/by/4.0/

(c) (i) Open Access

\begin{abstract}
It is of great knowledge nowadays that the use of fossil fuels is responsible for the emission of gases that intensify the greenhouse effect, which threatens the survival of the humankind. The gravity of this fact could be mitigated through the indirect use of solar energy for fuels derived from vegetable that can be planted and cultivated by the world of renewable and non-polisher. Microalgae play an important role in this regard, as they have promising characteristics as potential raw material for the production of biofuels, able to absorb large amounts of $\mathrm{CO}_{2}$. Chlorophyll organisms convert these simple substances in the atmosphere, absorbing sunlight into chemical energy stored, that is, compounds with high energy, biomass can also be used to obtain biocompounds human nutritional supplement and food animal, however, have been found an important number of difficulties to economically viable production like high cost of production of dry biomass and oil extraction. Here, we review the main approaches of biorefinery concept appearing as an alternative to achieve economic viability of the production of bio-diesel based on microalgae. The major points are the following: 1) use of re-residual water, 2) marketing of Carbon Credits, and 3) development of co-products resulting from high value added.
\end{abstract}

\section{Keywords}

Biodiesel, Biorefinery, Microalgae

\section{Introduction}

Current trends in energy supply and use are unsustainable-economically, environmentally and socially. Without decisive action, energy related to greenhouse gas emissions will be more than double by 2050 and the grow- 
ing demand for oil will increase concerns about security of supply. We can and must change the way we are today. The energy-carbon technologies will play a crucial role in the energy revolution needed to make this change happen [1].

Biofuels marketed today are bioethanol and biodiesel. There is a wide variety of conventional conversion technology and advanced biofuels. The processes of conventional biofuels, despite already commercially available continue to improve in efficiency and economy. The advanced conversion routes are moving into the demonstration phase or are already there.

Biodiesel, a renewable source of biofuel derived for use in internal combustion engines with compression ignition, contributes to the reduction in global temperature of the planet and the health costs, provides employment and income, is fully miscible with mineral diesel oil increases Fuel lubricity improving engine performance, it is biodegradable and non-toxic [2].

The raw material for biodiesel production can be divided into three categories: vegetable oils, animal fats and oils and waste fats. All vegetable oils and animal fats, waste or not, are triglycerides of fatty acids which can be processed into biodiesel. Form major sources used today, such as soybeans, have low productivity per area planted oil well that are used for food and feed [3]. That is why, as a promising source of lipids for biodiesel production chain, microalgae arise as a biomass having a high fat content (20\% - 50\%), this being obtained naturally from the carbon dioxide conversion atmospheric when using photosynthesis and helping with that, the removal of $\mathrm{CO}_{2}$ from the atmosphere [4].

The use of algae is of great importance also for the production of high value-added products (spirulina, astaxanthin, carotenoids, etc.). Despite the great interest that the use of algae for biofuel and byproducts has aroused, the problems are still viewed as important. The potential recognized: high oil yield (60\%), rapid growth, land use and low cost opportunity resources do not compete with food and $\mathrm{CO}_{2}$ capture and use. Therefore, investments have been significant, however, is even better understanding of the necessary basic principles for the commercial scale-up viable, fundamental R \& D and applied even seem necessary. Within the main themes of research and development are the growing costs, harvesting and oil extraction, recycling of water and nutrients, as well as the added value of co-products.

Many authors admit that the cultivation of algae for biofuel industry cannot be profitable in itself. The use of co-products with high added value, such as "nutraceuticals”, fertilizer and energy production from waste biomass of algae is required.

No doubt the concept of biorefinery should be applied, since the oils represent only one of many products with commercial value. An integrated system requires not only that the algal biomass directly feeds the biorefinery, but also the direct use of waste and exhaust gases (e.g., synthesis gas, methane, heat, carbon dioxide, sewage, etc.) or the biorefinery power plant in the new algae production systems.

In the quest for viability of microalgae production process does need to address the concept of biorefinery where the benefits take advantages and the high value-added products can be exploited.

\section{Biorefinery Approach}

In the past, little attention was dedicated to the development of techniques for crops to maximize the value of the products obtained from microalgae (biorefining). The oils represent only one of many products with commercial value, and the choice of the body to grow requires the evaluation of all the materials potentially produced.

Depending on the type of algae chosen and the growing conditions, marine biomass is able to accumulate significant amounts of bio-based products (proteins. oils, carbohydrates, starch, vitamins); diatoms often accumulate oils, green algae: starch and oils, and the golden algae: oils and carbohydrates [5].

They can also give compounds included in the field of fine chemicals such as PUFAs, pigments, sugars and antioxidants [6]. Its biochemical composition can be modulated by different growth conditions, are induced to produce high concentrations of great commercial importance components and the yield of oil can be significantly improved [7].

In case of micro-algae systems, energy production has to be combined with for example waste water treatment and/or the co-production of value-added products (food, feed, materials, chemicals) to make the overall cultivation/processing concept economically feasible [8].

After oil extraction, the remaining biomass can be processed for the production of bioethanol, used as animal feed and fertilizer, it is a source of nitrogen and phosphorus or simply burned to generate power [9]. 
The technical potential of marine crops for greenhouse gas abatement has been recognized for many years, given their ability to use $\mathrm{CO}_{2}$, and the possibility of achieving higher productivities than terrestrial crops. Biofuel production from these marine crops, including overall sustainability aspects, is now an Increasing topic of discussion. Microalgal biomass production can perform waste $\mathrm{CO}_{2}$ biofixation $(1 \mathrm{~kg}$ dry algal biomass using about $1.83 \mathrm{~kg}$ of $\mathrm{CO}_{2}$ ) [7]; therefore the $\mathrm{CO}_{2}$ emitted in the burning biodiesel can be reabsorbed by plants and microalgae [9].

The biomass production potentially could significantly be increased by the application of high-efficient fully integrated aquatic biomass cultivation-processing systems, i.e. "Marine Biorefineries" (Figure 1) [5].

An integrated system requires not only that the algal biomass directly feeds the biorefinery, but also the direct use of waste and exhaust gases (e.g., synthesis gas, methane, heat, carbon dioxide, sewage, etc.) or the biorefinery power plant in our new algae production systems.

The general idea of the concept of Biorefinery Aquatic (applicable to microalgae) is the algal biomass processing for value-added products and by-products, heat and power. The use of aquatic biomass offers the possibility of a significant increase in the availability of domestic biomass to bio-refineries processing, it should be considered particularly for regions with limited biomass supply [10].

Another study demonstrated economic viability refers to the microalgae production process for electricity generation, which is considered as a joint activity with ethanol in order to meet the expected increase in power demand. The production of this alternative energy source in conjunction with an ethanol plant maximizes both gains and brings benefits to the environment, with the microalgae capturing the carbon dioxide emitted by the ethanol plant. This process occurs through the burning of biomass of these microorganisms for each ton of biomass burned are generated 8.12 MWh. That would be a sustainable alternative to increase the supply of electric power in Brazil, for the burning of algal biomass does not release more $\mathrm{CO}_{2}$ than was consumed in production, so it is a power "zero emission", this also happens with the water from washing cane system [11]. This would certainly reduce the microalgae production costs for the generation of bioelectricity. On the other hand there is also the possibility of selling the $\mathrm{O}_{2}$ released in photosynthesis process as additional revenue. It is estimated that for every ton of $\mathrm{CO}_{2}$ absorbed release at approximately $500 \mathrm{~kg}$ of $\mathrm{O}_{2}$.

\section{Marine Biorefinery}

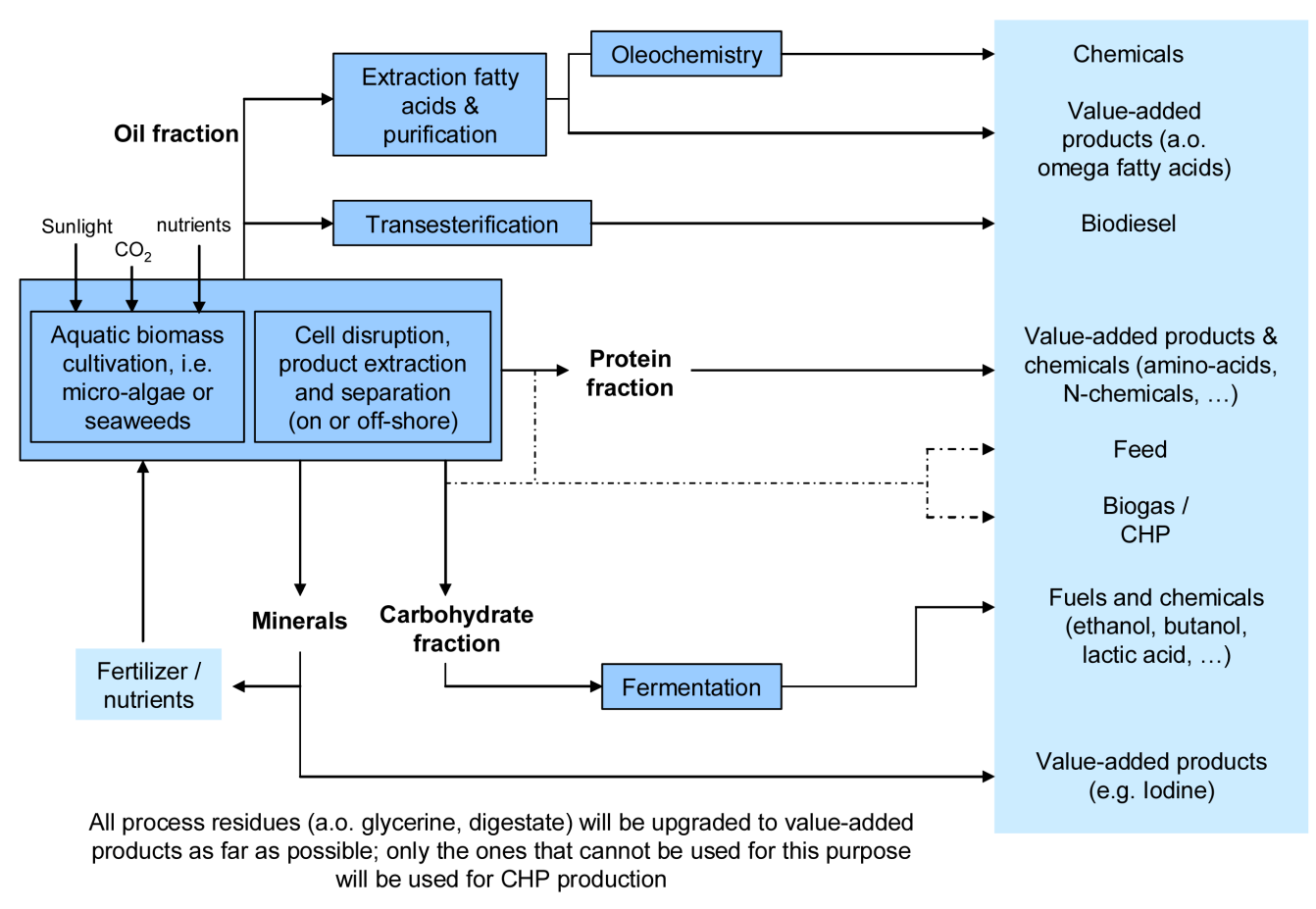

Figure 1. Marine biorefinery. 
According [12] for the use of biomass in the preparation of food and extraction of substances of interest it is necessary to separate the biomass from the culture medium, which involves solid phases: liquid as flocculation, centrifugation and filtration. Then the biomass can be dried by techniques such as sun drying, in a "spray drying" or lyophilization. The compounds of microalgae cells are extracted by using cell disruption methods homogenization, ultrasound, osmotic shock, solvents, enzymes, among others. From this point, substances of interest can be recovered by purification processes (ultrafiltration, chromatography or fractionation).

\section{Value-Added Products}

\subsection{Polyunsaturated Fatty Acids}

Great importance has been given to the provision of sources of polyunsaturated fatty acids. This is due to changes in the human diet, in recent centuries, and marked appearance of a number of diseases related to low intake of these compounds, as well as their recognized therapeutic significance, especially those of Omega-3 family [13].

The lipid content of the microalgal biomass can vary from 1 to $40 \%$ by dry weight, and in certain growing conditions, can reach $85 \%$ [14]. The algal lipids are typically composed of glycerol, sugars or bases and esterified fatty acids containing from 12 to 22 carbons, and may be both saturated as mono-or polyunsaturated. Fatty acids correspond to larger fraction of lipids and, in some species, the PUFA ("polyunsaturated fatty acids") represent between 25 and $60 \%$ of total lipids [14] [15].

The PUFAs particularly of $\omega-3$ and $\omega$-6 series and EPA, DHA and AA are considered to be pharmacologically important for dietary and therapeutic use against inflammatory diseases (rheumatism, inflammations of the gastrointestinal mucosa) [9].

According to [13] [16]-[19], PUFAs have role in prevention and treatment of a variety of cardiovascular diseases, atherosclerosis, arrhythmia, lowering blood pressure, lowering cholesterol and triglyceride levels plasma, cancer and are apparently essential in infant nutrition and brain development [12].

Among the known species of microalgae that have significant amounts of omega-3 PUFA and omega-6 families, are representatives Haptophyceae (Isochrysis spp., and Pavlova lutheri (Droop) Green), Bacillariophyceae (Phaeodactylum tricornutum, Thalassiosira spp., and Odontella aurita (Lyngbye) Agardh), Dinophyceae (Crypthecodinium cohnii (Seligo) Javornick), Rhodophyceae (Porphyridium cruentum Nägeli) and smaller quantity of Chlorophyceae [20]. According [21], polyunsaturated fatty acids microalgal origin has a very promising market in biotechnology, particularly in the functional food industry.

The [22] ingredients database shows that, for example, the overall volume of omega-3 consumption, used in addition to processed foods, reported a surprising increase 50 times between 2004 and 2009. In terms of regional consumption Western Europe claims nearly half of the total value, followed by North America and in Eastern Europe. The $44 \%$ is applied in industrial/packaged bread, $32 \%$ of oils and fats functional, and $20 \%$ for dairy products.

Regarding the fatty acid extraction methods as $\omega 3, \omega 6$, it can be made by the evaporation method using a thin film evaporator, which has been converted into a fundamental tool in the industry for evaporation operations in extreme conditions [23]. It can also be made by molecular distillation although it is very costly [24]. Enzymatic hydrolysis also provides a promising alternative that also could save energy and increase the selectivity of the product, while the use of traditional chemical methods (chromatographic separation, molecular distillation, etc.) to produce concentrated $\omega 3$ PUFAs require the use of extreme pHs and high temperatures, which can partially destroy the structure of the double bonds all cis $\omega 3$ PUFA natural oxidation, isomerization or migration [25].

Although currently DHA and EPA oil prices from algae cannot compete with oil from fish, mainly due to the high cost of microalgae production. Taking into account economic technical studies demonstrates that the biological productivity, geographical location and production technology are important factors to improve the economy of the process [26].

\subsection{Carotenoids}

The three main groups of pigments found in microalgal biomass are the chlorophylls, carotenoids and phycobilins (phycobiliproteins) [27]. According [17], it is possible to increase the synthesis of these compounds through manipulation of the cultivation conditions, usually by some environmental stress. 
The carotenoid pigments of great commercial interest, act as sunscreens and as secondary photosynthetic pigments, and each species may contain between 5 and 10 kinds of the universe of approximately 60 different carotenoids present in microalgal cells. Several species can accumulate high concentrations of beta-carotene, astaxanthin or canthaxanthin, which have a wide application as natural dyes and as antioxidants [21].

The increasing industrial interest in these natural pigments can be explained by the capacity allocated to them to prevent degenerative diseases: fighting free radicals and function as anticancer agents and stimulants of the immune system [28]. Compared to synthetic dyes are more resistant to the presence of ascorbic acid, heat, freezing processes, and exhibit effectiveness even when applied in small amounts in food [29]. The strict regulations for the application of synthetic dyes in the food industry, encourages research aimed at productive development and use of microalgae carotenoids as a food additive [30].

In the case of beta-carotene is generally found in a fraction less than $1 \%$ of the dry mass but can be accumulated to approximately $10 \%$ by halotolerants species (grow in high salt concentration), like those of the genus Dunaliella [27]. The beta-carotene microalgae source has been marketed in three forms: extracts, powders and as dry biomass. According [31], the price of this product varies between $\$ 300.00$ and US $\$ 3000.00$ per kilogram, according to the product quality and demand. For this reason might result as a possibility to make more feasible the biofuel production process based on microalgae since significant increase revenue.

The direct saponification of wet microalgae biomass for the production of fatty acids and subsequently Obtaining biodiesel, presents itself as a promising and fast process reducing the operating team and cost, as well as products such as Allows values of antioxidant carotenoid (unsaponificable) high value added for industrial applications [32].

\subsection{Protein}

Before a new food be declared safe for human consumption, it becomes necessary to go through a series of detailed toxicology tests to prove the safety of the product. This applies especially to unconventional protein sources, where the microalgae are grouped. All tests, including human studies revealed no evidence that would limit the use of algae material properly processed [33]. Many chemical composition analyses of different algae have been published in the literature, in Table 1 shown a compilation of some species in relation to the protein content and also of carbohydrates and lipids [34].

Of the species listed on top, only a few have been selected for their large-scale production. Although, despite their high nutritious protein content, not gained significant importance as a food substitute. The main obstacles

Table 1. Composition of some algae especies (\% in dry biomass).

\begin{tabular}{cccc}
\hline Alga & Protein & Carbohydrates & Lipids \\
\hline Anabaena cylindrical & $43-56$ & $25-30$ & $4-7$ \\
Aphanizomenon flos-aquae & 62 & 23 & 3 \\
Chlamydomonas rheinhardii & 48 & 17 & 21 \\
Chlorella pyrenoidosa & 57 & 26 & $14-22$ \\
Chlorella vulgaris & $51-58$ & $12-17$ & 6 \\
Dunaliella salina & 57 & $14-18$ & $14-20$ \\
Euglena gracilis & $39-61$ & $40-57$ & $9-14$ \\
Porphyridium cruentum & $28-39$ & $10-17$ & $12-14$ \\
Scenedesmus obliquus & $50-56$ & $33-64$ & $11-21$ \\
Spirogyra sp. & $6-20$ & $13-16$ & $6-7$ \\
Arthrospira maxima & $60-71$ & $8-14$ & $4-9$ \\
Spirulina platensis & $46-63$ & 63 & 15 \\
Synechococcus sp. & & & 11 \\
\hline
\end{tabular}


are the consistency of the dry powder biomass, dark-green color, and its light fishy smell, which limits the incorporation of algal material in conventional food material. On the other hand, the microalgae production costs are still too high to compete with conventional sources of protein.

To date, the main sales take place in microalgae called health food market. However, the use of microalgae as animal feed is more recent. A large number of nutritional and toxicological evaluations demonstrated the ability of algal biomass as a valuable dietary supplement or replacement of conventional sources of protein (soybean meal, fish meal, rice bran, etc.)

The reference [35] has selected a series of microalgae products combinations with wide range. Assuming $40 \%$ lipids, $50 \%$ protein and $10 \%$ carbohydrates, it could be sold a quarter of lipids for the food and chemical industries for $€ 2 / \mathrm{kg}$, the rest for biodiesel to $€ 0.50 / \mathrm{kg}$. The $20 \%$ of soluble protein for human consumption $€ 5 / \mathrm{kg}$, and the rest (80\%) in feed $€ 0.75 / \mathrm{kg}$.

\section{Use of the Residual Water}

At present, it has thought much in water reuse alternative in industrial processes as well as reuse of wastewater and sewage and other effluents from other industries. In Figure 2 it is shown how the water can be reused to take advantage of the nutrients contained in it and reduce water consumption [36].

Clearly for the production of biodiesel would be needed to optimize the cheaper cost system, with consequent cost savings in all areas (water use, nutrient, energy, infrastructure, etc.), an alternative that is being thought is the use of industrial or domestic wastewater (as a source of nutrients) and the own infrastructure (or additions) of an Effluent Treatment Plant (WWTP) with stabilization pond system, obtaining microalgae biomass [37].

Microalgae as a way to minimize the costs of the final product (microalgae oil) can be obtained directly from a system where they are already naturally available due to providing the optimal environmental conditions for their development. Microalgae fed by effluent, in a stabilization pond system, may be used to obtain a cheaper oil when compared to oil obtained in culture systems [38]. This will lead to a saving of water and nutrients, as well as serve for the removal of effluent nutrients such as nitrogen and phosphorus. Aquaculture systems involving the production of microalgae and the waste water treatment (for example, amino acids, enzymes or food industry waste waters) seem to be very promising for the cultivation of microalgae combined with the biological purification [39].

In studies on the potential of microalgae assessment of waste as an alternative to the biodiesel production chain it has concluded that the lipid content obtained (around 16\%) from the microalgae of facultative pond resembles the levels obtained from microalgae biomass cultured in conventional processes, compared to literary data, having, therefore, potential for use in the production of biodiesel. Obtaining microalgae biomass directly from the facultative pond, shows up as an alternative to processes for the production of algal biomass traditionally used (fotobioreator and aerated tanks), as well as recover the microalgae biomass failing to launch it in the stream, and it can have an economic and environmental gain while the biodiesel production could minimize the environmental impacts of the high presence of this material in environment [39].

The Spanish University of Malaga developed another interesting study in conjunction with the School of

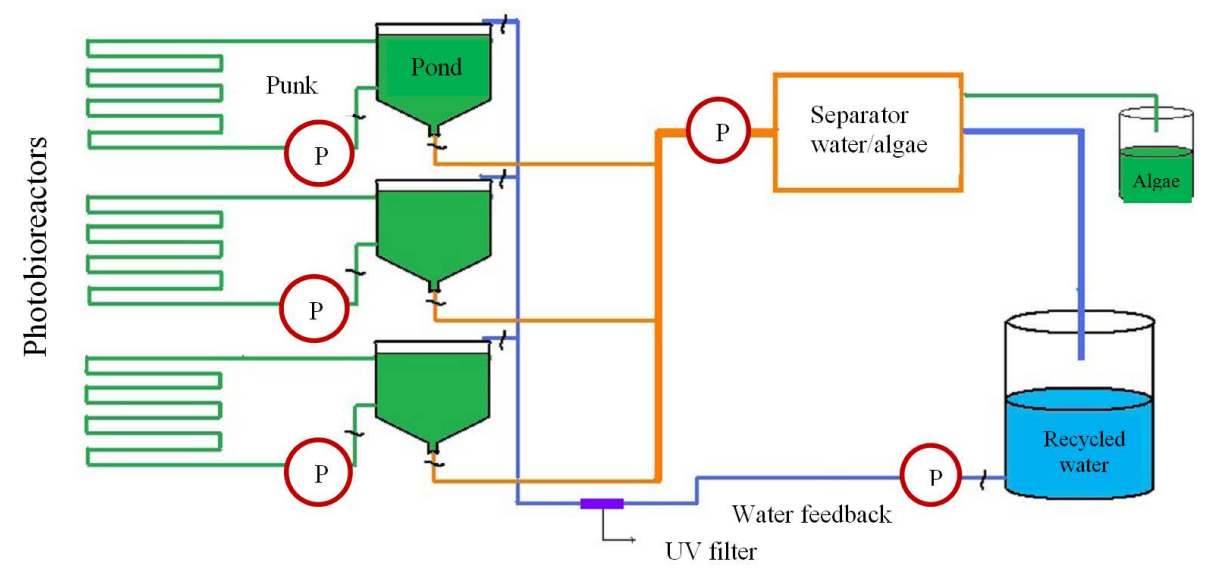

Figure 2. Water recycling scheme in the cultivation of microalgae. 
Chemistry of UFRJ, which shows some results obtained with the cultivation of microalgae Scenedesmus dimorphus using a source of swine wastewater. When the culture is fed with waste water introduced is more concentrated and more intense green color. When observed under a microscope, the colonies are significantly larger along the growing period. He has appeared in the residual medium, which growth continues for longer leading to a higher biomass concentration [10].

The removal of nutrients in the crops Scenedesmus dimorphus using waste water was determined by comparing the concentrations of nitrates and nitrites, ammonia and phosphate in the culture medium at the beginning and end of the cultures. The results showed an almost complete absorption of these nutrients during the cultivation period. The absorption of phosphate was $89.1 \%$, while the absorption of nitrogenous compounds and ammonia was above $99 \%$ (Table 2) [10].

Given the possibility that the waste water can be obtained without additional costs, there is an opportunity to involve the growth of some species the treatment of swine waste water thus achieving: on the one hand, achieving a low cost biomass with significant lipid content, and on the other hand, treatment of these waters which are rich in nutrients such as phosphates and nitrates, which in the case of discharge to water bodies contribute to pollution and eutrophication of these ecosystems.

For future studies should seek a balance between nutrient removal in waste water and the production of lipids, aiming to maximize this last aspect [10]. The amounts of lipids and other components of Scenedesmus dimorphus biomass are shown in Table 3.

\section{5. $\mathrm{CO}_{2}$ Absorption}

Currently, the level of $\mathrm{CO}_{2}$ in the atmosphere is the cause of climate change that governments wish to control. Withdrawal mechanisms of $\mathrm{CO}_{2}$ through reuse is an alternative offered by bio-fixation process for microalgae [40].

Industrial activity and power generation in thermal cast into the atmosphere each year, about 20 billion tons of $\mathrm{CO}_{2}$. Among the various alternatives to capture and use of $\mathrm{CO}_{2}$ is the use of microalgae [41].

To reduce the concentration of atmospheric $\mathrm{CO}_{2}$ exists as a possibility to reduce emissions or absorption of the $\mathrm{CO}_{2}$ produced in excess, called carbon sequestration. Some measures to reduce current levels of $\mathrm{CO} 2$ in the atmosphere have been proposed in the Kyoto Protocol in 1997, which states that developed countries would have to reduce by 5\% the emission of gases that cause the "greenhouse effect" by 2012 [42].

Among all photosynthetic and autotrophic organisms capable of removing $\mathrm{CO}_{2}$ from gas streams, microalgae are the group that support up to $50 \% \mathrm{CO}_{2}$ and the presence of other compounds such as $\mathrm{NO}$ and $\mathrm{SO}_{2}$ [41] [43].

Table 2. Initial and final concentrations of nutrients phosphates, nitrates and nitrites, and ammonia and their removal percentages of the microalga Scenedesmus dimorphus.

\begin{tabular}{cccc}
\hline Nutrients & \multicolumn{3}{c}{ Cultivation with wastewater } \\
\cline { 2 - 4 } & Beginning & Final & \% Remotion \\
\hline Total phosphate $(\mu \mathrm{g} / \mathrm{L})$ & 2419.70 & 263.51 & 89.1 \\
Nitrate + nitrite $(\mu \mathrm{g} / \mathrm{L})$ & 3001.46 & 1.83 & 99.9 \\
Ammonia $(\mu \mathrm{mol} / \mathrm{L})$ & 64.05 & 0.09 & 99.9 \\
\hline
\end{tabular}

Table 3. Chemical composition (\% dry weight) of Scenedesmus dimorphus biomass.

\begin{tabular}{cc}
\hline Components & Dry weight (\%) \\
\hline Humidity & $3.21 \pm 0.20$ \\
Total protein & $49.53 \pm 0.01$ \\
Total lipids & $12.58 \pm 0.08$ \\
Carbohydrates & $21.36 \pm 0.15$ \\
Ash & $13.32 \pm 0.17$ \\
\hline
\end{tabular}


In this context, the microalgae are highlighted in reducing concentrations of greenhouse gases due to the photosynthetic capacity and its applicability in systems engineering in the solar energy leads to $\mathrm{CO}_{2}$ fixation converting the thermal energy-rich biomass into energy with added value-added generating chemicals and food [44].

It is estimated that carbon fixation by microalgae crop in top condition would surroundings of 11 - 36 ton. C ha/year, representing a yield of approximately three to thirteen times the values reported for the reforestation (3 4 ton $\mathrm{C}$ ha/year) [42]. Studies on the removal of $\mathrm{CO}_{2}$ and $\mathrm{NO}$ generated during combustion of coal microalgae have reported removing maximum values of $22.97 \% \mathrm{CO}_{2}, 27.13 \% \mathrm{NO}$ and which can reduce costs of the nutrient culture medium and problems generated by issuing gases[43].

A viable strategy for carbon sequestration based on photosynthetic microalgae as conceptually shown in Figure 3 is possible, where the $\mathrm{CO}_{2}$ generated in the combustion of fossil fuels and nutrients are added to a photobioreactor in which the micro-algae use sunlight to convert photosynthetic $\mathrm{CO}_{2}$ in high-value compounds. The advantages of using a system based on microalgae are [45]:

- High purity $\mathrm{CO}_{2}$ gas is not necessary for the cultivation of algae. Combustion gases containing variable quantities of $\mathrm{CO}_{2}$ can be fed directly to culture microalgae. This will simplify the separation of $\mathrm{CO}_{2}$ from flue gas significantly.

- Some combustion products such as NOx or SOx can be effectively used as nutrients for microalgae. This could simplify flue gas cleaning the combustion system.

- The planned process is a renewable cycle with minimal negative impacts on environment.

$\mathrm{A} \mathrm{CO}_{2}$ recovery model from gas chimneys to redirect the microalgae cultivation tanks was developed by [46], and the basic design based on typical thermal emissions, with potential 50e of $500 \mathrm{MW}$, and recovery efficiency of $86.60 \%$ per year. The estimated operating cost of the process, including the extraction of monoethanolamine (MEA), compression of $1500 \mathrm{psi}$, dehydration, transportation to the tanks (assuming distance of $100 \mathrm{Km}$, supplying approximately $100 \%$ of the $\mathrm{CO}_{2}$ recovered the tanks, was estimated at $\$ 4050$ and $\$ 57.10$ per ton of $\mathrm{CO}_{2}$ redirected to the plants $500 \mathrm{MW}$ and 50 respectively. The model also assessed the efficacy of direct use of the stack gas, however, this option had $40 \%$ more expensive costs than MEA process which has been used as a technology for $\mathrm{CO}_{2}$ recovery with lower gas pressures. The model also concludes that the transport step equals approximately $8 \%$ of the operating costs of the MEA process and can reach $20 \%$ of the costs for direct pumping process from chimneys. These data demonstrate the advantages of the decentralized production and microalgae complex located adjacent to $\mathrm{CO}_{2}$ emissions units, impacting directly on reducing process costs.

Another model is a process that recovers high purity $\mathrm{CO}_{2}$ from flue gases using membranes. A stream of $\mathrm{CO}_{2}$ and $\mathrm{O}_{2}$ is emitted as a product, and $\mathrm{O}_{2}$ can be recycled to enrich the gas stream entering the membrane concentrator. Preliminary economic studies are in favor, obtaining an operating cost of $\$ 21.00$ per ton of $\mathrm{CO}_{2}$ recovered [47]. This cost estimate is close to that obtained for a more recent model, which estimates an operating cost of $\$ 16.00$ to $\$ 22.00$ per ton of $\mathrm{CO}_{2}$ recovered [48].

However operating costs estimated for these models, available technology at the time, has been overcome by the use of new technologies cheaper, and some authors have consider that this process is available at low or no

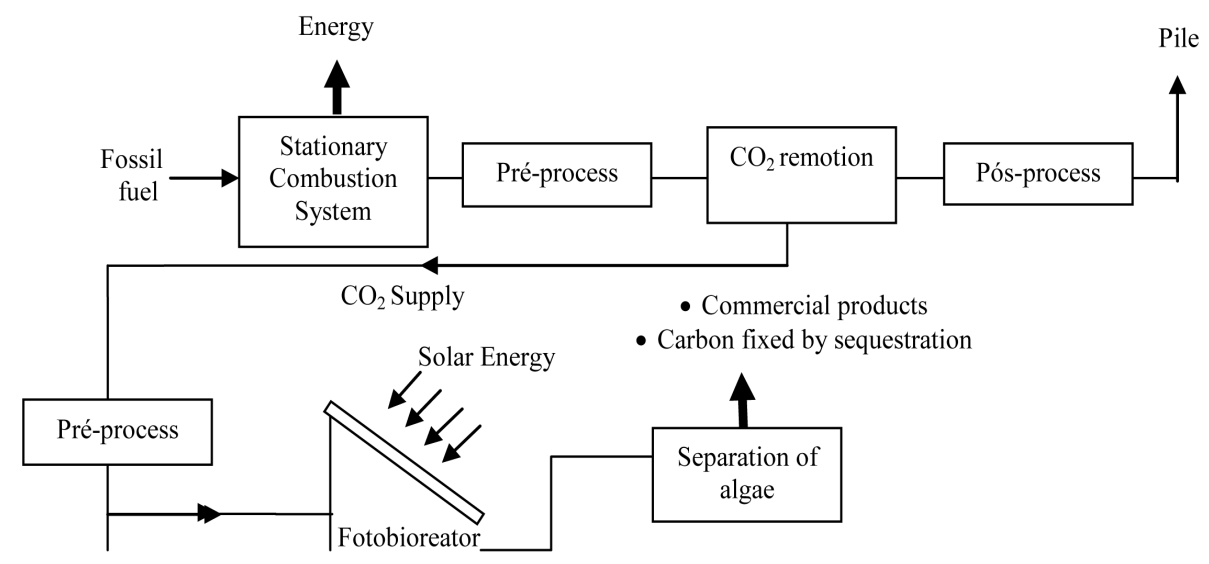

Figure 3. Conceptual carbon sequestration scheme based on microalgae. 
cost [4], however, it is necessary to analyze various parameters that significantly affect this estimate. Currently it can be assumed the operating cost of US $\$ 1.00$ per tonne of $\mathrm{CO}_{2}$ recovered, including the steps of collecting and forwarding to the $\mathrm{CO}_{2}$ tanks, with a $99 \%$ efficiency in the recovery of $\mathrm{CO}_{2}$. Implementation costs of these processes can fluctuate according to the sizing of equipment such as compressors and tubing, which are designed according to the characteristics of emissions from each chimney [49].

Another study of microalgae Spirulina sp. and Scenedesmus obliquus with gas combustion of coal-fired Thermal Power Plant of President Medici (UTPM) operated by CGTEE (Thermal Generation Company of Electric Power), installed in southern Brazil. It demonstrated that the use of flue gas from the UTPM increased by $35.0 \%$ the production of biomass at the end of the growing Spirulina sp. a reduction of $24.2 \%$ of the $\mathrm{CO}_{2}$ concentration of the combustion gas being biofixado $5.7 \% \mathrm{CO}_{2}$ for growth of microalgae. The final biomass of microalgae S. obliquus and Spirulina cultivated with flue gas had 6.2 and $4.8 \%$ lipids, and 40.6 and $46.8 \%$ protein, respectively. The results show that micro-algae can be grown in power plants for biofixar $\mathrm{CO}_{2}$ from coal combustion gas and contribute to reducing the global warming [41].

\section{Carbon Credits}

Concern for the environment has led the countries of the United Nations to sign an agreement stipulating control over human interventions in the climate. This agreement was born in December 1999 with the signing of the Kyoto Protocol. Thus, it was determined that signatory developed countries to reduce their emissions of greenhouse gases by 5.2\% on average for the year 1990 between 2008 and 2012. This period was also known as the first commitment period. Not to compromise the economies of these countries, the protocol established that part of this reduction could be made through negotiation with nations through the flexibility mechanisms (en.wikipedia.org).

One of the flexibility mechanisms is the Clean Development Mechanism (CDM). The CDM carbon credits is called Certified Emission Reduction (CER)-or in English, Certified Emission Reductions (CER). One CER corresponds to one tonne of carbon dioxide equivalent. The carbon credits or Certified Emission Reduction (CER) certificates are issued to a person or company that has reduced its emissions of greenhouse gases (GHG).

Each ton of $\mathrm{CO}_{2}$ that is absorbed (carbon sequestration) or the amount of greenhouse gases that are no longer produced by the company classified as pollution is converted into a carbon credit unit, which is traded in dollars on the world market. Reducing the emission of other gases, also generators of the greenhouse effect can also be converted into carbon credits, using the concept of Carbon Equivalent.

Buy carbon credits in the market is about to buy a permit to emit greenhouse gases. The price of this permission, traded on the market, must necessarily be lower than the fine that the issuer must pay to the government, to issue GHG. For the sender, so buy carbon credits in the market means, in practice, get a discount on the fine due. International agreements such as the Kyoto Protocol determine a maximum quota of greenhouse gases that developed countries can emit. The countries, in turn, create laws restricting GHG emissions. Thus, those countries or industries that fail to meet emissions reduction targets, become carbon credit buyers. On the other hand, those industries that have managed to reduce their emissions below certain dimensions, can sell at market prices, the surplus of "emission reduction" or "emission allowance" in the national or international market [50]. The carbon credit market is in full development, mainly because of so-called voluntary market. In it, even countries that do not need to lower their emissions or that have not signed the Kyoto Protocol are able to trade credits.

\section{Conclusion}

This paper, like the title suggest, has presented a brief overview about biodiesel from microalgae focused in biorefinery concept. It has been exposed some alternatives that can help to reduce the high cost of biodiesel production based in microalgae, turn it more feasible. It has become clear that when it manages to integrate the production of biodiesel with the other value-added products and integrating with other pollutants and industries with large wastewater emissions, could bring significant economic benefits.

\section{Acknowledgements}

We would like to acknowledge the valuable contributions of GranValle Biodiesel Factory, who gave the idea and the support to develop this review and to the financial agency (FAPERJ) for the support given. 


\section{References}

[1] International Energy Agency (2011) Technology Roadmap Biofuels for Transport. https://www.iea.org/publications/freepublications/publication/Biofuels Roadmap WEB.pdf

[2] Encarnação, A.P.G. (2008) Geração de Biodiesel pelos Processos de Transesterificação e Hidroesterificação, Uma Avaliação Econômica, MsC. Thesis, Rio de Janeiro, Brazil.

[3] Amaral, M.A.P. and Da Costa, R.C. (2010) Brazilian Biodiesel Market and Future Prospects. Mercado Brasileiro de Biodiesel e Perspectivas Futuras. BNDES Setorial, 31, 253-280. Biocombustíveis.

[4] Chisti, Y. (2007) Biodiesel from Microalgae. Biotechnology Advances, 25, 294-306. http://dx.doi.org/10.1016/j.biotechadv.2007.02.001

[5] Ree, R.V. and Annevelink, B. (2007) Status Report Biorefinery, Agrotechnology and Food Sciences Group. Wagenongen.

[6] Wang, B., Li, Y., Wu, N. and Lan, C.Q. (2008) $\mathrm{CO}_{2}$ Bio-Mitigation Using Microalgae. Applied Microbiology and Biotechnology, 79, 707. http://dx.doi.org/10.1007/s00253-008-1518-y

[7] Brennan, L. and Owende, P. (2010) Biofuels from Microalgae-A Review of Technologies for Production, Processing, and Extractions of Biofuels and Co-Products. Renewable and Sustainable Energy Reviews, In Press, Corrected Proof. 2010. http://dx.doi.org/10.1016/j.rser.2009.10.009

[8] Reith, J.H. (2004) Sustainable Co-Production of Fine Chemicals and Energy from Microalgae: Public Final E.E.T. Duurzame co-productie van fijnchemicaliën en energie uit micro-algen: Openbaar eindrapport E.E.T. Project K99005/ 398510-1010. Petten, Energieonderzoek Centrum Nederland. ftp://ftp.ecn.nl/pub/www/library/report/2004/c04037.pdf

[9] Mata, T.M., Martins, A.A. and Caetano, N.S. (2010) Microalgae for Biodiesel Production and Other Applications: A Review. Renewable and Sustainable Energy Reviews, 14, 217-232. http://dx.doi.org/10.1016/j.rser.2009.07.020

[10] Arceo, A.A. (2012) Produção de biodiesel mediante o processo de Hidroesterificação do óleo de microalgas. PhD. Thesis, Federal University of Rio de Janeiro, Brazil.

[11] Holanda, L.R. and Ramos, F.S. (2011) Analysis of the Economic Viability of the Generated Energy through the Microalgae. Electronic Magazine of Management and System. Análise da Viabilidade econômica da Energia gerada através das microalgas. Revista Eletrônica Sistemas e Gestão, 6, 327-346. http://dx.doi.org/10.7177/sg.2011.v6.n3.a7

[12] Derner, R.B., et al. (2006) Microalgae, Products and Applications. Microalgas, produtos e aplicações. Scielo: Revista Ciência Rural, 36, 1959-1967.

[13] Simopoulos, A.P. (2002) The Importance of the Ratio of Omega-6/Omega-3 Essential Fatty Acids. Biomedecine \& Pharmacotherapy, 56, 365-379. http://dx.doi.org/10.1016/S0753-3322(02)00253-6

[14] Becker, W. (2004) Microalgae in Human and Animal Nutrition. In: Richmond, A., Ed., Handbook of Microalgal Culture: Biotechnology and Applied Phycology, Blackwell Science, London, 566 p.

[15] Brown, M.R. (1991) The Amino-Acid and Sugar Composition of 16 Species of Microalgae Used in Mariculture. Journal of Experimental Marine Biology and Ecology, 145, 79-99. http://dx.doi.org/10.1016/0022-0981(91)90007-J

[16] Radwan, S.S. (1991) Sources of $\mathrm{C}_{20}$-Polyunsaturated Fatty Acids for Microbiological Use. Applied Microbiology Biotechnology, 35, 421-430. http://dx.doi.org/10.1007/BF00169743

[17] Borowitzka, M.A. (1993) Products from Microalgae. Infofish International, 5, 21-26.

[18] Fábregas, J., et al. (1994) Decrease of Plasma Cholesterol with the Marine Microalgae Dunaliella Tertiolecta in Hypercholesterolemic Rats. Journal of General Microbiology, 40, 553-540.

[19] Gill, I. and Valivety, R. (1997) Polyunsaturated Fatty Acids, Part 1: Occurrence, Biological Activities and Applications. Trends in Biotechnology, 15, 401-409. http://dx.doi.org/10.1016/S0167-7799(97)01076-7

[20] Yongmanitchai, W. and Ward, O.P. (1991) Screening of Algae for Potential Alternative Sources of Eicosapentaenoic Acid. Phytochemistry, 30, 2963-2967. http://dx.doi.org/10.1016/S0031-9422(00)98231-1

[21] Pulz, O. (2004) Photobioreactors: Production Systems for Phototrophic Microorganisms. Applied Microbiology and Biotechnology, 57, 287-293.

[22] Euromonitor International (2012) Fortification of Foods with Omega-3 Shows Strong Growth. Additives and Ingredients. Fortificação de alimentos com Ômega-3 mostra forte crescimento. Aditivos e Ingredientes. http://www.insumos.com.br/aditivos_e_ingredientes/materias/194.pdf

[23] ZEAN Consultores (2013) Thin Film Evaporators. Application: Distillation of Glycerin. Evaporadores de películas finas. Aplicación: Destilación de glicerina. www.interempresas.net

[24] Pedroni, J.M. (2013) The Molecular Distillation and Its Applications in the Industry of Oils and Fats. El destilador 
molecular y sus aplicaciones en la industria de aceites y grasas. www.oleosegorduras.org.br

[25] Brudy Technology (2013) New Omega-3 Enzyme. Scientific Update. Nuevos ácidos grasos OMEGA-3 Enzimáticos. Actualización Científica.

[26] Chauton, M.S., et al. (2015) Techno-Economic Analysis of Industrial Production of Marine Microalgae as a Source pf EPA and DHA-Rich Raw Material for Aquafeed: Research Challenges and Possibilities. Aquaculture, 436, 95-103. http://dx.doi.org/10.1016/j.aquaculture.2014.10.038

[27] Abalde, J., Cid, A., Fidalgo, J., Torres, E. and Herrero, C. (1995) Microalgae: Cultivation and Applications. Microalgas: cultivo e aplicaciones. Monography No. 26, Coruña University, A Coruña, 210 p.

[28] Orosa, M., et al. (1997) Production and Analysis of Secondary Carotenoids in Green Algae. Journal of Applied Phycology, 12, 553-556. http://dx.doi.org/10.1023/A:1008173807143

[29] Skulberg, O.M. (2004) Bioactive Chemicals in Microalgae. In: Richmond, A., Ed., Handbook of Microalgal Culture: Biotechnology and Applied Phycology, Blackwell Science, Oxford, 485-512.

[30] Campo, J.A., et al. (2000) Carotenoid Content of Chlorophycean Microalgae: Factors Determining Lutein Accumulation in Muriellopsis sp. (Chlorophyta). Journal of Biotechnology, 76, 51-59. http://dx.doi.org/10.1016/S0168-1656(99)00178-9

[31] Ben-Amotz, A. (2004) Industrial Production of Microalgal Cell-Mass and Secondary Products-Major Industrial Species: Dunaliella. In: Richmond, A., Ed., Handbook of Microalgal Culture: Biotechnology and Applied Phycology, Blackwell Science, Oxford, 273-280.

[32] Díaz, G.C., Cruz, Y.R., Fortes, M.M., Viegas, C.V., Carliz, R.G., Furtado, N.C. and Aranda, D.A.G. (2014) Primary Separation of Antioxidants (Unsaponifiables) the Wet Biomass Microalgae Chlamydomonas sp. and Production of the Biodiesel. Natural Science, 6, 1210-1218. http://dx.doi.org/10.4236/ns.2014.615108

[33] Chamorro, G. (1980) Toxicological Study of Spirulina Algae Pilot Plant Producing Protein (Spirulina Sosa Texcoco SA). Etude toxicologique de l'algue Spirulina plante pilote productrice de protéines (Spirulina de Sosa Texcoco S.A.) UF/MEX/78/048, UNIDO/10.387.

[34] Becker, E.W. (2007) Micro Algae as a Source of Protein. Medical Clinic, Department II, University of Tübingen, Immunopathological Laboratory, Otfried-Müller-Str-10, 72076 Tübingen, Germany. http://science.naturalnews.com/pubmed/17196357.html

[35] Wijffels, R., Barbosa, M. and Eppink, M.H.M. (2010) Microalgae for the Production of Bulk Chemicals and Biofuels. Biofuels, Bioproducts and Biorefining, 4, 287-295. http://dx.doi.org/10.1002/bbb.215

[36] Mulder, J.P. and Oliveira, P.E. (2010) Microalgae: The New Energy. Micro-Algas: A Nova Energia. Mimeo, Recife/ PE: UFPE.

[37] Mulbry, W., Konrad, S., Pizarro, C. and Kebedee-Westhead, E. (2008) Treatment of Dairy Manure Effluent Using Freshwater Algae: Algal Productivity and Recovery of Manure Nutrients Using Pilot-Scale Algal Turf Scrubbers. Bioresource Technology, 99, 8137-8142. http://dx.doi.org/10.1016/j.biortech.2008.03.073

[38] Sawayama, S., Inoue, S., Dote, Y. and Yokoyama, S. (1995) $\mathrm{CO}_{2}$ Fixation and Oil Production through Microalga. Energy Conversion and Management, 36, 729-731. http://dx.doi.org/10.1016/0196-8904(95)00108-P

[39] Cardoso, A. and Vieira, G.G. (2010) Evaluation of the Potential of Residual Microalgae as an Alternative to the Biodiesel Production Chain. Avaliação do potencial das microalgas residuais como uma alternativa à cadeia produtiva do biodiesel. Testing and Development Laboratory on Biomass and Biofuels_LEDBIO, Federal University of Tocantins.

[40] García, L.M., García, A.I. and Morna, A. (2007) Isolation and Selection of Microalgae Species for the $\mathrm{CO}_{2} \mathrm{Bio-Fixa-}^{-}$ tion. Journal of Biotechnology, 131, 122-126.

[41] Radmann, E.M., Camerini, F.V., Santos, T.D. and Costa, J.A.V. (2011) Isolation and application of SOX and NOX Resistant Microalgae in Biofixation of $\mathrm{CO}_{2}$ from Thermoelectricity Plants. Energy Conversion and Management, 52, 3132-3136. http://dx.doi.org/10.1016/j.enconman.2011.04.021

[42] Morais, M.G., Costa, J.A.V., et al. (2008) Bioprocesses for Removing Carbon Dioxide and Nitrogen Oxide Microalgae Order to Use Gases Generated during the Combustion of Coal. Bioprocessos para remoção de dióxido de carbono e óxido de nitrogênio por microalgas visando a utilização de gases gerados durante a combustão do carvão. Química Nova, 31, 1038-1042. http://dx.doi.org/10.1590/S0100-40422008000500017

[43] Harun, R., Singh, M., Forde, G.M., et al. (2009) Bioprocess Engineering of Microalgae to Produce a Variety of Consumer Products. Renew Sustain Energy, 14, 1037-1047. http://dx.doi.org/10.1016/j.rser.2009.11.004

[44] Borges, L., et al. (2007) Carbon Absorption Potential for Microalgae Species Used in Aquaculture: First Steps towards the Development of a "Clean Development Mechanism”. Potencial de absorção de carbono por espécies de microalgas usadas na aqüicultura: primeiros passos para o desenvolvimento de um "mecanismo de desenvolvimento limpo". Atlântica, Rio Grande, 29, 35-46. 
[45] Olaizola, M., et al. (2004). Microalgal Removal of $\mathrm{CO}_{2}$ from Flue Gases: $\mathrm{CO}_{2}$ Capture from a Coal Combustor. Mera Pharmaceuticals, Inc., Kailua-Kona, Physical Sciences Inc., Andover.

[46] Kadam, K.L. (1997) Power Plant Fuel as a Source of $\mathrm{CO}_{2}$ for Microalgae Cultivation: Economic Impact of Different Process Options. Energy Conversion and Management, 38, S505-S510. http://dx.doi.org/10.1016/S0196-8904(96)00318-4

[47] Walke, L., et al. (1998) Recovery of $\mathrm{CO}_{2}$ from Fuel Gas Using in Electrochemical Membrane. Gas Separation and Purification, 2, 72-76. http://dx.doi.org/10.1016/0950-4214(88)80015-X

[48] Ijima, M., et al. (2003) Fuel Gas $\mathrm{CO}_{2}$ Recovery and Compression Cost Study for $\mathrm{CO}_{2}$ Enhanced Oil Recovery. In: Gale, J. and Kaya, Y., Eds., Greenhouse Gas Control Technologies-6th International Conference, Pergamon Press, Oxford, 109-114. http://dx.doi.org/10.1016/B978-008044276-1/50018-0

[49] Borges, F.C. (2010) Proposta de um modelo Conceitual de biorrefinaria com estrutura descentralizada. MsC. Thesis, Federal University of Rio Grande do Sul, Porto Alegre.

[50] Wikipedia (2012) Carbon Credits. Créditos de carbono. http://pt.wikipedia.org/wiki/Cr\%C3\%A9ditos_de_carbono 